\title{
Integration of Commercial Microbiological Products into Soil Fertility Practices as a Potential Option for Acclimatization and Growth of TC Banana in Kenya
}

\author{
Agnes Mumo Kavoo-Mwangi ${ }^{1,2,3}$, Esther M. Kahangi'2, Elijah Ateka², Justus Onguso², \\ Joyce M. Jefwa ${ }^{3}$ \\ ${ }^{1}$ Crop Science Department, School of Agriculture and Biotechnology, Karatina University, Karatina, Kenya \\ ${ }^{2}$ Department of Horticulture, School of Agriculture, Jomo Kenyatta University of Agriculture and Technology, \\ Nairobi, Kenya \\ ${ }^{3}$ Tropical Soil Biology and Fertility Institute of the International Centre for Tropical Agriculture (TSBF-CIAT), \\ Nairobi, Kenya \\ Email: agneskavoo@yahoo.com
}

Received 22 May 2014; revised 27 June 2014; accepted 12 July 2014

Copyright (C) 2014 by authors and Scientific Research Publishing Inc.

This work is licensed under the Creative Commons Attribution International License (CC BY). http://creativecommons.org/licenses/by/4.0/

(c) (i) Open Access

\section{Abstract}

Tissue culture (TC) banana plantlets at the in vitro stage are delicate and devoid of microbes and nutrients that are essential for establishment and subsequent growth. Some microbes are known for function best under certain soil threshold levels of macro and micronutrients and have been associated with growth and performance of TC banana. A green house and field study was conducted to evaluate the effect of combining two commercial biological products [Rhizatech and ECO-T (mycorrhiza and Trichoderma based products, respectively)] with various sources of nitrogen and phosphorous including Mavuno, Minjingu phosphate rock, Calcium Ammonium Nitrate (CAN), manure and diammonium phosphate (DAP) on growth and performance of TC banana in Vertisol and Rhodic Ferralsol soil conditions. Tissue culture plants were initially inoculated with Rhizatech and ECO-T at the acclimatization stage and subsequently at the beginning of the potting stage and field establishment. Addition of nutrient sources was also done at the same stages of plant growth by mixing with the soil substrates prior to planting. The performance of plants was significantly (at $p \leq 0.05$ ) affected by the combinations of nutrient sources depending on the soil type and stage of plant development. The growth of plants in the Vertisol increased with Trichoderma combined with either organic manure, DAP or combined with a macro and micro nutrient source (Mavuno) as compared to the sole application of Trichoderma. Performance of plants treated with combination of mycorrhiza and either Mavuno and minjigu rock phosphate was con- 
sistently higher in the Rhodic Ferralsol than either mycorrhiza alone or fertilizer alone. This indicates that TC plants could highly benefit from combined application of microbiological products and inorganic and organic fertilizers. However, a prior knowledge of the product's microbial formulation and prevailing soil conditions is essential for optimizing the potential benefits of integrating microbe-based product with inorganic and organic fertilizers.

\title{
Keywords
}

\author{
Microbiological Products, Soil Fertility Practices, Integration, Tissue Culture Banana, \\ Growth and Performance
}

\section{Introduction}

Tissue culture banana plantlets offer an excellent means for providing pest- and disease-free planting material to farmers [1] [2]. However, tissue culture (TC) plants are fragile, devoid of food reserves and therefore more prone to shock, which may lead to loss of plantlets at establishment. With decline in soil fertility and increase in soilborne pests and diseases, TC plants are likely to succumb to disease and roots may not establish well in low fertility soil environments [3].

Banana requires large amounts of nitrogen and potassium followed by phosphorus, calcium and magnesium to maintain high yields [4] [5]. To fulfill the plant demand for nutritional attributes, it is essential to apply those elements in the soil which mostly come from inorganic chemical sources. The increased use of chemical fertilizer is undesirable because its production is an energetically costly process and considerable pollution is caused through both the production and use of mineral $\mathrm{N}$-fertilizers. This is exacerbated by the relatively low efficiency of their uptake by the plants due to non-extensive root system and may also delete soil organic matter in the long term [6]-[8]. Inoculant biofertilizers are more environmentally sound and their introduction in agricultural production systems could be one of the means to mitigate the onset of global warming as well as the reduction in fertilizer input costs, prevent depletion of organic matter and increase crop yields [9]-[11].

Inoculation of tissue culture banana with biofertilizers such as mycorrhiza (AMF) and Trichoderma has been reported to stimulate root growth, nutrient uptake, enhance plant establishment and increase growth, yield and protection against disease and pest infestation [12]-[16]. The growth vigor acquired by biologically inoculated TC banana plants under nursery conditions is expected to give the plants an advantage during field establishment especially in nutritionally and disease challenged soils. However, the functionality of some of the rhizospheric microbes used for constituting biofertilizers such as mycorrhiza (AMF) and Trichoderma is greatly influenced by the prevailing soil conditions. Nitrogen $(\mathrm{N})$, phosphorous $(\mathrm{P})$ and other nutrients such as zinc, copper and sulphur levels in the soil affect the functioning of these microorganisms [17]-[21]. Mycorrhizal symbiosis benefits, for example, have been suggested to be optimal at P levels of $50 \mathrm{mg} \cdot \mathrm{kg}^{-1}[21]$.

Organic and inorganic fertilizers are used primarily to increase nutrient availability and the type or amount of fertilizer added to soil could directly affect the function performed by the various microbial groups in the soil [22]. Mineral nutrition is essential for growth, sporulation and stimulation of fungal secondary metabolism [18] and combining of mineral and bio fertilizers could greatly benefit both the added microbes and inoculated plant as well as improve soil quality [11] [23]-[25].

Previous studies have focused on the effect of long term fertilization on indigenous microbial diversity and efficiency [26] [27] but little is reported on the effect of combining commercial microbiological strains with fertilizers in nutrient poor soils that have little or no history of fertilization.

Although several formulations of mycorrhiza and Trichoderma are available in the market, their efficacy on plant growth is variable depending on the soil nutrient levels. It is therefore essential to add these nutrients in levels that enable optimal functioning of the micro-organisms and consequent promotion of nutrient uptake and plant growth. The integration of microbiological products with fertilizers could address the soil fertility constraint faced by TC banana plantlets, especially under field conditions. This study focused on evaluating the potential of integrating microbiological products with inorganic and organic fertilizers on growth and performance of tissue cultured banana in Vertisol and Rhodic Ferralsol soil conditions under nursery and field conditions. 


\section{Materials and Methods}

\subsection{Source of Tissue Cultured Materials, Soil Properties and Inoculation Process}

Tissue culture banana plantlets cv. Gros Michel, were obtained from Jomo Kenyatta University of Agriculture and Technology (JKUAT) Biotechnology laboratory.

The experimental soils (Vertisol and Rhodic Ferralsol) were sampled from two banana growing regions in Kenya namely, Western Kenya (Bondo) and Coastal Kenya (Kilifi) (Table 1) at a depth of $0-20 \mathrm{~cm}$ and used for hardening and potting of tissue culture plantlets. Soil nutrient composition (Nitrogen, Phosphorous, Potassium, Carbon, Magnesium, Calcium, Sodium), Cation Exchange Capacity (CEC), pH and soil texture composition (\% Clay, \% Sand and \% Silt) were determined according to standard procedures [28] [29]. The initial soil characteristics are described in Table 2.

\subsection{Green House Experiment}

A $2 \times 2 \times 3$ factorial experiment comprising of 1) two microbiological products a) Rhizatech b) ECO-T; 2) soil substrates a) Vertisol (sampled from Western Kenya-Bondo) b) Rhodic Ferralsol (sampled from coastal Kenya-Kilifi) and; 3) Fertilizers a) Minjingu phosphate rock (MPR) and CAN as sources of phosphorous (P), $\mathrm{Mg}$, Ca and eight more essential micronutrients (Mwaluko, 1996) and nitrogen (N), b) Mavuno as a source of N, $\mathrm{P}$, potassium (K) and micronutrients such as calcium $\mathrm{Ca}, \mathrm{Mg}$, sulphur (S) and other essential micronutrients including boron (B), manganese (Mn), zinc $(\mathrm{Zn})$, molybdate $(\mathrm{Mo})$ and copper $(\mathrm{Cu}) \mathrm{c}$ ) manure and diammonium phosphate (DAP) as a source of $\mathrm{P}, \mathrm{N}$ and carbon (C). Three replicates consisting of 16 plants per replicate were considered per treatment. Control experimental units (without product addition) were also included with three replicates per soil. The experimental units were arranged in a completely randomized design under greenhouse conditions. The microbiological products are described in Table 3. Application of products was done as recom-

Table 1. Description of soils used for hardening and potting of tissue culture banana.

\begin{tabular}{cc}
\hline $\begin{array}{c}\text { Site of soil } \\
\text { collection }\end{array}$ & Description of soil \\
\hline $\begin{array}{c}\text { Western Kenya } \\
\text { (Bondo) }\end{array}$ & $\begin{array}{r}\text { Vertisol: dark montmorillonite with swelling properties, heavy cracking when dry; poorly drained, leaching } \\
\text { of weathering minerals limited, high in Ca and Mg, pH. Low hydraulic conductivity; N, } \\
\text { P and micronutrient deficient; no P-fixation [33]. }\end{array}$ \\
$\begin{array}{c}\text { Coastal Kenya } \\
\text { (Kilifi) }\end{array}$ & $\begin{array}{r}\text { Rhodic Ferralsol: developed on limestone, reddish brown to weak red top soil, weak to moderate } \\
\text { texture silty clay texture with low nutrient status, especially low in N and P. Deeply weathered soil, } \\
\text { moderately fertile, texture loamy sandy with slightly acid pH [33]. }\end{array}$ \\
\hline
\end{tabular}

Modified from [30].

Table 2. Initial soil characteristics $(0-20 \mathrm{~cm})$ of Rhodic Ferralsol and Vertisol, used for establishing tissue culture banana under greenhouse conditions.

\begin{tabular}{cccc}
\hline Soil property & Units & Rhodic Ferralsol & Vertisol \\
\hline $\mathrm{pH}\left(\mathrm{H}_{2} \mathrm{O}\right)$ & & 6.9 & 5.87 \\
Olsen P & $\left(\mathrm{mg} \cdot \mathrm{P}^{*} \mathrm{~kg}^{-1}\right)$ & 7 & 3 \\
$\mathrm{~K}$ & $\left(\mathrm{cmolc} \cdot \mathrm{kg}^{-1}\right)$ & 0.6 & 0.82 \\
$\mathrm{Ca}$ & $\left(\mathrm{cmolc} \cdot \mathrm{kg}^{-1}\right)$ & 4 & 25.99 \\
$\mathrm{Mg}$ & $\left(\mathrm{cmolc} \cdot \mathrm{kg}^{-1}\right)$ & 1.7 & 12.53 \\
$\mathrm{Na}$ & $\left(\mathrm{cmolc}^{-1} \mathrm{~kg}^{-1}\right)$ & 0.1 & 0.19 \\
$\mathrm{ECEC}$ & $\left(\mathrm{cmolc} \cdot \mathrm{kg}^{-1}\right)$ & 7 & 52.5 \\
$\mathrm{~N}$ & $(\%)$ & 0.1 & 0.25 \\
$\mathrm{C}$ & $(\%)$ & 1 & 3.67 \\
$\mathrm{Clay}$ & $(\%)$ & 19.7 & 54.7 \\
Sand & $(\%)$ & 76.3 & 20.3 \\
Silt & $(\%)$ & 4.0 & 25 \\
\hline
\end{tabular}

Modified from [30]. 
Table 3. Description of microbe-based commercial products used in the experiments.

\begin{tabular}{|c|c|c|c|c|c|}
\hline Product & Manufacturer & Composition & $\begin{array}{l}\text { Asserted non-active } \\
\text { ingredients }\end{array}$ & Dose & $\begin{array}{l}\text { Mode of } \\
\text { application }\end{array}$ \\
\hline ECO-T & $\begin{array}{l}\text { Plant Health } \\
\text { Products (Pty) Ltd., } \\
\text { South Africa } \\
\text { Distributed by } \\
\text { Lachlan Ltd., Kenya }\end{array}$ & $\begin{array}{l}\text { Spores of Trichoderma harzianum } \\
\text { strain Rifai KRL AG2 (4.8\%) }\end{array}$ & $\begin{array}{l}\text { Kaolin clay } \\
(95.2 \%)\end{array}$ & $\begin{array}{c}0.25 \mathrm{~g} \\
\text { per } 3 \mathrm{~m}^{2}\end{array}$ & $\begin{array}{l}\text { Dry powder } \\
\text { applied to soil }\end{array}$ \\
\hline Rhizatech & $\begin{array}{l}\text { Dudutech (K) } \\
\text { Ltd., Kenya }\end{array}$ & $\begin{array}{l}\text { Spores and mycelial fragments of } \\
\text { arbuscular mycorrhizal fungi species: } \\
\text { Glomus mosseae, G. etunicatum, G. } \\
\text { intraradices and G. aggregatum). } \\
\left(50 \text { propagules } / \mathrm{cm}^{3}\right)\end{array}$ & Not specified & $\begin{array}{c}60 \\
\mathrm{~kg} \cdot \mathrm{ha}^{-1}\end{array}$ & $\begin{array}{l}\text { Granules applied } \\
\text { to soil }\end{array}$ \\
\hline
\end{tabular}

CFU, colony forming units. PHC Colonize AG coded as PHC Colonize in the manuscript (modified from [30]).

mended by the manufacturers. Application rates per plant corresponded to the recommended rate in the field, converted using the medium planting density for banana (2500 plants·ha ${ }^{-1}$ ). The area of pots used for establishing plants was considered when determining the exact amount of inoculum to be added per pot. The mode of application of products is described in Table 3. ECO-T was applied at $1.25 \mathrm{~g} / \mathrm{L}$, and Rhizatech at $2 \mathrm{~g} / \mathrm{plant}$ Three replicates consisting of 10 plants per replicate were considered per treatment. Fertilizer application rates followed the recommended fertilizer rates and were applied at the hardening, potting and at field establishment by mixing with the soil substrate. The areas of pot used for establishing plants were considered when determining the exact amount of microbiological inoculum to be added per pot.

\subsection{Inoculation Process}

Inoculation of plantlets with products, soil sterilization (Vertisol and Rhodic Ferralsol soils), acclimatization and maintenance under high humidity conditions was done according to standard procedures [30]. The inoculation strategy applied for initial inoculation of deflasked plantlets at the acclimatization stage and subsequently at the potting (8 weeks after deflasking) and field establishment stages (22 weeks after deflasking) is shown in Figure 1.

\subsection{Study Site Description and Experimental Design under Field Conditions}

The experiment was carried out at two sites with similar soil conditions as those used for hardening and potting of plants at under green house nursery conditions. Tissue cultured banana plants established under green house conditions were used as planting materials and established in two agro ecological zones (Western Kenya in Bondo and Coastal Kenya in Kilifi). The experimental design followed a multilocational complete block design in four farms per study site. Each farm was considered as a replicate. Diammonium phosphate (DAP) and Minjigu rock phosphate fertilizers, used as sources of phosphorous were applied at the rate of $50 \mathrm{~kg}$ per hectare. Calcium Ammonium Nitrate (CAN) used as a source of nitrogen was applied at the rate of $120 \mathrm{~kg}$ per hectare. Mavuno fertilizer which was used as a source of macro and micro nutrients was applied at the manufacturers recommended rate of $185 \mathrm{~kg}$ per hectare. High quality farm yard manure was considered as a source of organic nitrogen and carbon and was applied at 6 tonnes per hectare. Application rates per plant corresponded to the recommended rate in the field, converted using the medium planting density for banana (2500 plants $\left.\cdot \mathrm{ha}^{-1}\right)$.

\subsection{Planting and Crop Management}

Medium planting density of 2500 plants per hectare was adopted hence the plants were spaced at $2 \mathrm{~m}$ by $2 \mathrm{~m}$ and established in $60 \times 60 \times 60 \mathrm{~cm}$ planting pits. Guard row plants were established three meters away from the experimental plants only in edge plots, hence surrounding the entire farm. The inner $2 \mathrm{~m} \times 2 \mathrm{~m}$ inner mats were monitored and evaluated up to the on-set of flowering of the mother plant. Fertilizer was mixed with top soil and incorporated around the banana plant in the pit followed by topping with sub-soil before planting. Hand weeding was done when needed avoiding the use of tools that could mutilate superficial banana roots. Desuckering of plants was carried out in order to have a 1-2-3 system (mother, first ratoon, second ratoon), preferably with a circular movement of plants, so that original planting density was maintained. Deleafing (leaves having $<50 \%$ of 

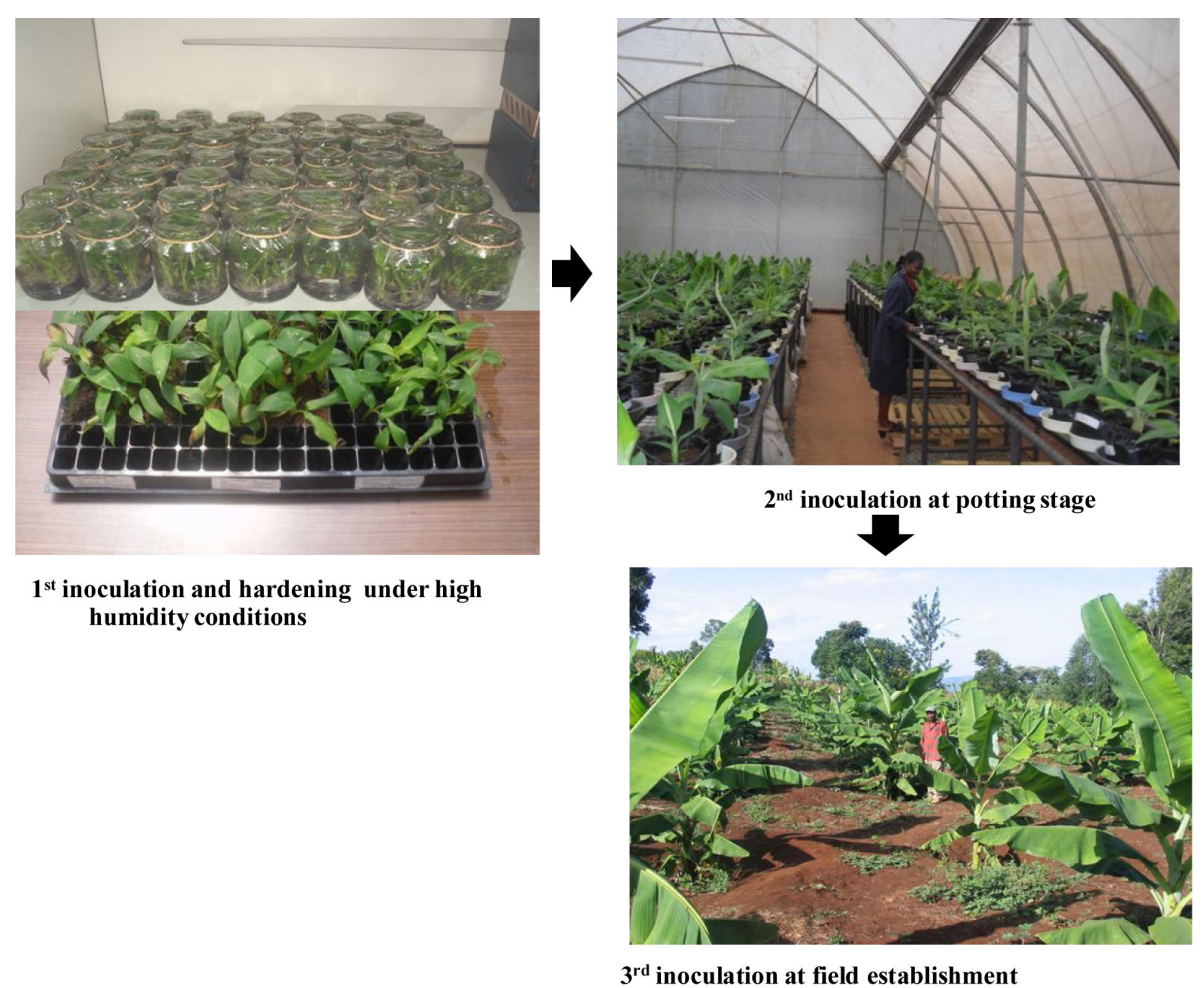

Figure 1. Strategy for inoculating micropropagated banana plantlets.

functional leaf surface area) and watering during periods of severe drought stress were also part of the management practices carried out.

\subsection{Assessment of Growth Parameters}

Plant growth parameters such as shoot height (from base), length and width of the second leaf from the sword shoot, girth (at two centimeters from the base) of the stem, and number of functional leaves were recorded every two weeks under greenhouse conditions and every two months under field conditions up to the on-set of flowering stage. Only treatments with a high number of surviving plants under green house conditions were considered for field establishment.

\subsection{Data Analysis}

To assess the effects of products, soils, fertilizers and the interaction between soils, products and fertilizers, data were subjected to analyses of variance (ANOVA) using the mixed procedure of SAS [31]. Means found to be significant at $\mathrm{p} \leq 0.05$ were separated using Tukey’s HSD test.

\section{Results}

\subsection{Integration of Microbiological Products with Fertilizers on Growth and Performance of Tissue Cultured Plants}

The effect of combining products with various fertilizers was evident in both Vertisol and Rhodic Ferralsol. Highly significant $(\mathrm{p} \leq 0.001)$ differences between treatments were observed on all plant growth parameters evaluated in both soils (Table 4 and Table 5). In the Rhodic Ferralsol, the highest plant height was observed on plants treated with combined application of Rhizatech and Mavuno with an increase of $136 \%$ and $116.5 \%$ compared to the non-treated control and sole application of Rhizatech, respectively (Table 4). The highest number of leaves (10), which was statistically different from all other treatments, was observed with the combined application of minjigu rock phosphate and CAN (MRPCAN). Plants treated with combined application of ECO-T 
Table 4. Growth of tissue cultured banana plants treated with microbiological products and different fertilizers in Rhodic Ferralsol, 22 weeks after deflasking.

\begin{tabular}{|c|c|c|c|c|c|c|}
\hline Product & Fertilizer & Height & NOL & Girth & LL & LW \\
\hline None & None & $8.0 \mathrm{a}$ & $7.7 \mathrm{a}$ & $1.7 \mathrm{a}$ & $15.6 \mathrm{a}$ & $5.6 a$ \\
\hline ECOT & None & $10.9 \mathrm{~b}$ & $7.8 \mathrm{a}$ & $1.6 \mathrm{a}$ & $19.8 \mathrm{~b}$ & 7.1abc \\
\hline Rhizatech & None & $8.7 a$ & 8.2ab & $1.6 \mathrm{a}$ & 16.9a & $5.7 a$ \\
\hline None & MRPCAN & $11.8 \mathrm{~b}$ & $9.1 \mathrm{c}$ & $1.8 \mathrm{a}$ & $19.5 b$ & 6.8ab \\
\hline ECOT & MRPCAN & $11.0 \mathrm{~b}$ & $8.7 \mathrm{bc}$ & $2.6 \mathrm{~b}$ & $20.1 \mathrm{~b}$ & 7.1abc \\
\hline Rhizatech & MRPCAN & $13.7 \mathrm{c}$ & $9.9 \mathrm{~d}$ & 1. $9 \mathrm{ab}$ & $24.6 c$ & 8.7cd \\
\hline None & Manure + DAP & 13.6c & $7.7 \mathrm{a}$ & $1.84 \mathrm{ab}$ & $19.2 \mathrm{~b}$ & 6.9abc \\
\hline ECOT & Manure + DAP & $16.8 \mathrm{e}$ & 8.6bc & $2.1 \mathrm{ab}$ & $26.7 d$ & $9.1 \mathrm{~d}$ \\
\hline Rhizatech & Manure + DAP & $15.3 \mathrm{~d}$ & $8.9 b c$ & $2.0 \mathrm{ab}$ & $23.6 \mathrm{c}$ & 6.9abc \\
\hline None & Mavuno & $18.4 \mathrm{f}$ & $8.7 \mathrm{bc}$ & 2.2ab & $24.3 \mathrm{c}$ & $8.7 \mathrm{~cd}$ \\
\hline ECO-T & Mavuno & 16.6de & $7.8 \mathrm{a}$ & 2.1ab & 23.8 & 8.5bcd \\
\hline Rhizatech & Mavuno & $18.9 \mathrm{f}$ & $8.4 a b c$ & $2.1 \mathrm{ab}$ & $25.0 \mathrm{~cd}$ & $11.1 \mathrm{e}$ \\
\hline \multicolumn{7}{|l|}{ SED } \\
\hline Product & & 0.197 & 0.112 & 0.115 & 0.314 & 0.275 \\
\hline Fertilizer & & 0.227 & 0.129 & 0.133 & 0.363 & 0.318 \\
\hline Product $\times$ Fertilizer & & 0.393 & 0.224 & 0.23 & 0.628 & 0.551 \\
\hline \multicolumn{7}{|l|}{$\mathrm{p}$ value } \\
\hline Product & & $<0.001$ & $<0.001$ & 0.147 & $<0.001$ & $<0.001$ \\
\hline Fertilizer & & $<0.001$ & $<0.001$ & $<0.001$ & $<0.001$ & $<0.001$ \\
\hline Product $\times$ Fertilizer & & $<0.001$ & $<0.001$ & 0.068 & $<0.001$ & $<0.001$ \\
\hline
\end{tabular}

Means of 16 plants replicated three times. Within the same column, means followed by the same letter are not significantly different (Tukey's HSD test) at $\mathrm{p}>0.05$. NOL, number of leaves; LL, leaf length; LW, leaf width. Leaf length and leaf width measured in centimeters.

Table 5. Shoot and root growth of tissue cultured banana plants treated with microbiological products and different fertilizers in Rhodic Ferralsol, 22 weeks after deflasking.

\begin{tabular}{ccccc}
\hline Product & Fertilizer & SDWT (g) & RDWT (g) & NOSR \\
\hline None & None & 2.1 & $1.8 \mathrm{ab}$ & $14.3 \mathrm{a}$ \\
ECOT & None & 4.3 & $2.1 \mathrm{ab}$ & $19.3 \mathrm{ab}$ \\
Rhizatech & None & 2.5 & $1.2 \mathrm{a}$ & $14.7 \mathrm{ab}$ \\
None & MRPCAN & 5.4 & $3.4 \mathrm{ab}$ & $21 \mathrm{ab}$ \\
ECO-T & MRPCAN & 3.3 & $3.5 \mathrm{ab}$ & $19 \mathrm{ab}$ \\
Rhizatech & MRPCAN & 3.7 & $2.8 \mathrm{ab}$ & $18 \mathrm{ab}$ \\
None & Mavuno & 7.3 & $6.3 \mathrm{ab}$ & $24 \mathrm{ab}$ \\
ECO-T & Mavuno & $5.1 \mathrm{ab}$ & $24.3 \mathrm{ab}$ \\
Rhizatech & Mavuno & 6.5 & $2.7 \mathrm{ab}$ & $18 \mathrm{ab}$ \\
None & Manure + DAP & 4.9 & $4.5 \mathrm{ab}$ & $27.3 \mathrm{~b}$ \\
ECO-T & Manure + DAP & 3.4 & $6.1 \mathrm{~b}$ & $20 \mathrm{ab}$ \\
Rhizatech & Manure + DAP & 5.9 & $5.6 \mathrm{ab}$ & $24.7 \mathrm{ab}$ \\
SED & & 6.1 & & 1.547 \\
Product & & & 0.643 & 1.786 \\
Fertilizer & & 0.740 & 0.743 & 3.093 \\
Product $\times$ Fertilizer & & 0.855 & 1.287 & \\
p value & & 1.481 & 0.178 & 0.001 \\
Product & & 0.598 & 0.343 & 0.001 \\
Fertilizer & & 0.147 & 0.113 \\
Product $\times$ Fertilizer & & &
\end{tabular}

Means of 3 replicates. Within the same column, means followed by the same letter are not significantly different (Tukey's HSD test) at p > 0.05 . SDWT, shoot dry weight; RDWT, root dry weight; NOSR, number of secondary roots. 
and MRPCAN recorded the highest increase in girth of 55\% compared to the non-treated control, $44 \%$ and $63 \%$ compared to the application of MRPCAN alone and ECO-T alone. Leaf length was statistically different between most treatments with the longest leaf length observed on plants treated with combined application of ECO-T and manure and DAP. The combined application of ECO-T and manure and DAP increased leaf length by $71.3 \%$, 39.2\% and 34.8\% compared to the non-treated control, addition of manure and DAP alone and sole application of ECO-T respectively. Combining of Rhizatech with fertilizers also significantly affected leaf length recording an increase of 45.8\% (Rhizatech plus MRPCAN), 40.8\% (Rhizatech plus manure plus DAP) and 48.3\% (Rhizatech plus Mavuno) above the sole fertilizer applications. Effect of combining Rhizatech and Mavuno on leaf width was statistically different from all other treatments recording an increase of $100 \%$, 35.9\% and 96\% compared to the non-treated control and sole application of Mavuno and Rhizatech respectively. Other treatments with effects on leaf length statistically different from the non-treated control include Rhizatech plus MRPCAN, ECO-T plus manure plus DAP, Mavuno alone, ECO-T plus Mavuno and Rhizatech plus Mavuno increasing leaf length by 55.7\%, 62.6\%, 55.6\%, 52.7\% and 100\% respectively (Table 4).

Plants treated with manure alone in the Rhodic Ferralsol had significantly higher number of secondary roots (27) compared to the plants that received neither fertilizer nor product (un-treated control) and plants treated with Rhizatech (Table 5). Effects of all other treatments were statistically the same as the untreated control and Rhizatech. Combined application of fertilizer and products had no significant effects on shoot dry weights (SDWT) in the Rhodic Ferralsol. The highest SDWT (6.07 g) in the Rhodic Ferralsol were observed on plants treated with a combination of Rhizatech plus manure plus DAP and the least on untreated control plants. Plants treated with Rhizatech alone had significantly lower root dry weights (RDWT) (1.22 g) than plants treated with ECO-T plus manure plus DAP (6.11 g) and Mavuno alone (6.27 g) and statistically the same as all other treatments.

\subsection{Growth of Tissue Cultured Banana Treated with Microbiological Products and Different Fertilizers in a Vertisol Soil}

Under green house conditions, plant growth (height, girth, no. of leaves, leaf length and leaf width) was significantly affected by sole and combined application of products and fertilizers (Table 6). Effect of combined application of ECO-T plus manure plus DAP on plant height was statistically different from all other treatments increasing height by $110.6 \%, 33.7 \%$ and $51.5 \%$ compared to the non-treated control and sole application of manure plus DAP and ECO-T, respectively. Similar observations were made on plant girth, with combined application of ECO-T plus manure plus DAP increasing plant girth by $22.6 \%, 9.3 \%$ and $83.9 \%$ compared to the non-treated control and sole application of manure plus DAP and ECO-T respectively. Significant differences between treatments were observed on number of leaves with the highest number of leaves (11) observed on plants treated with sole application of MRPCAN. Most treatments negatively affected number of leaves up to a magnitude of $9.5 \%$.

Leaf length of plants treated with ECO-T and manure plus DAP was statistically different from all other treatments. An increase of 51.6\%, 25.4\% and $25.9 \%$ above the non-treated control and sole application of manure plus DAP and ECO-T, respectively was observed. Combined application of Rhizatech and Mavuno, ECO-T plus manure plus DAP, Rhizatech plus manure plus DAP, Rhizatech plus MRPCAN had similar effects but statistically higher leaf length than non-treated control, sole application of Rhizatech and combined application of ECO-T and MRPCAN (Table 6).

Combined application of fertilizer and products had no significant effects on shoot dry weights (SDWT) in the Vertisol (Table 7). The highest SDWT was observed with addition of Mavuno alone (13 g) and the least with application of Rhizatech plus MPRCAN) (3.87 g). The highest RDWT was observed with combined application of ECO-T plus manure plus DAP (7.45) and the least on the un-treated control plants. The number of secondary roots on plants treated with Mavuno fertilizer alone (31) was statistically different from plants treated with ECO-T (20) and mijingu rock phosphate plus CAN (MPRCAN) (20) but statistically the same as all other treatments (Table 7).

\subsection{Growth and Performance of Tissue Culture Banana Plants Treated with Microbiological Products and Different Fertilizers in Rhodic Ferralsol under Field Conditions}

Combining of microbiological products with fertilizers in Rhodic Ferralsol significantly $(\mathrm{p}<0.001)$ increased 
Table 6. Growth of tissue cultured banana plants treated with microbiological products and different fertilizers in a Vertisol, 22 weeks after deflasking.

\begin{tabular}{|c|c|c|c|c|c|c|}
\hline Product & Fertilizer & Height (cm) & Girth (cm) & NOL & $\mathrm{LL}(\mathrm{cm})$ & $\mathrm{LW}(\mathrm{cm})$ \\
\hline None & None & $11.7 \mathrm{a}$ & 2.1bcd & 10.7bcd & $23.6 a$ & $9.1 \mathrm{a}$ \\
\hline ECO-T & None & $16.3 c$ & $1.4 \mathrm{a}$ & $10.8 \mathrm{~cd}$ & $28.5 \mathrm{~cd}$ & 10.9bcde \\
\hline Rhizatech & None & $13.7 \mathrm{~b}$ & 2.1bcd & 10.6abcd & 25.2ab & $9.4 \mathrm{a}$ \\
\hline None & $\mathrm{MRP}+\mathrm{CAN}$ & $15.1 \mathrm{bc}$ & $2.0 \mathrm{bc}$ & $11.2 \mathrm{~d}$ & $26.8 \mathrm{bc}$ & $9.7 \mathrm{ab}$ \\
\hline ECO-T & $\mathrm{MRP}+\mathrm{CAN}$ & $15.6 \mathrm{c}$ & 2.4def & 10.1ab & $26.1 b$ & $9.2 \mathrm{a}$ \\
\hline Rhizatech & $\mathrm{MRP}+\mathrm{CAN}$ & $19.0 \mathrm{~d}$ & 2.3cde & 10.5abc & 29.1d & 11.4de \\
\hline None & Manure + DAP & $18.5 d$ & 2.4def & 10.5abc & 28.6cd & 10.1abc \\
\hline ECO-T & Manure + DAP & $24.7 \mathrm{~g}$ & $2.6 f$ & $10.5 a b c$ & $35.8 \mathrm{f}$ & $11.6 \mathrm{e}$ \\
\hline Rhizatech & Manure + DAP & $22.4 \mathrm{f}$ & $2.5 \mathrm{ef}$ & $10.5 \mathrm{abc}$ & 33.1e & 11.5de \\
\hline None & Mavuno & 19.7de & $1.9 \mathrm{bc}$ & $10.4 \mathrm{abc}$ & $28.4 \mathrm{~cd}$ & 10.3abcd \\
\hline ECO-T & Mavuno & $20.6 \mathrm{e}$ & $1.8 a b$ & $10.0 \mathrm{a}$ & $29.7 d$ & 11.1cde \\
\hline Rhizatech & Mavuno & $22.5 \mathrm{f}$ & $2.5 \mathrm{ef}$ & 10.4abc & 33.5e & $11.8 \mathrm{e}$ \\
\hline \multicolumn{7}{|l|}{ SED } \\
\hline Product & & 0.219 & 0.059 & 0.099 & 0.059 & 0.187 \\
\hline Fertilizer & & 0.253 & 0.068 & 0.115 & 0.068 & 0.215 \\
\hline Product $\times$ Fertilizer & & 0.439 & 0.117 & 0.199 & 0.117 & 0.373 \\
\hline \multicolumn{7}{|l|}{ p value } \\
\hline Product & & $<0.001$ & $<0.001$ & 0.006 & $<0.001$ & $<0.001$ \\
\hline Fertilizer & & $<0.001$ & $<0.001$ & 0.001 & $<0.001$ & $<0.001$ \\
\hline Product X Fertilizer & & $<0.001$ & $<0.001$ & $<0.001$ & $<0.001$ & $<0.001$ \\
\hline
\end{tabular}

Means of 16 plants replicated three times. Within the same column, Means followed by the same letter are not significantly different (Tukey's HSD test) at $\mathrm{p}>0.05$. NOL, number of leaves; LL, leaf length; LW, leaf width; MRPCAN, Minjigu Rock Phosphate + Calcium Ammonium Nitrate.

Table 7. Shoot and root growth of tissue cultured banana plants treated with microbiological products and different fertilizers in a Vertisol, 22 weeks after deflasking.

\begin{tabular}{|c|c|c|c|c|}
\hline Product & Fertilizer & SDWT(g) & RDWT(g) & NOSR \\
\hline None & None & 4.2 & 2.6 & 2.6 \\
\hline ECOT & None & 6.2 & 4.1 & 4.1 \\
\hline Rhizatech & None & 7.4 & 3.9 & 3.9 \\
\hline None & MRPCAN & 4.8 & 3.4 & 3.5 \\
\hline ECO-T & MRPCAN & 7.1 & 6.6 & 6.6 \\
\hline Rhizatech & MRPCAN & 3.9 & 3.8 & 3.8 \\
\hline None & Mavuno & 9.2 & 6.8 & 6.8 \\
\hline ECO-T & Mavuno & 7.7 & 6.5 & 6.5 \\
\hline Rhizatech & Mavuno & 8.7 & 5.8 & 5.8 \\
\hline None & Manure+DAP & 5.9 & 7.1 & 7.1 \\
\hline ECO-T & Manure+DAP & 4.6 & 7.4 & 7.4 \\
\hline Rhizatech & Manure+DAP & 5.6 & 5.6 & 5.6 \\
\hline \multicolumn{5}{|l|}{ SED } \\
\hline Product & & 1.023 & 0.676 & 1.483 \\
\hline Fertilizer & & 1.181 & 0.781 & 1.712 \\
\hline Product X Fertilizer & & 2.045 & 1.352 & 2.966 \\
\hline \multicolumn{5}{|l|}{ P value } \\
\hline Product & & 0.926 & 0.11 & 0.233 \\
\hline Fertilizer & & 0.041 & 0.001 & 0.003 \\
\hline Product X Fertilizer & & 0.458 & 0.47 & 0.023 \\
\hline
\end{tabular}

Means of 3 replicates. Within the same column, means followed by the same letter are not significantly different (Tukey's HSD test) at p > 0.05 . SWDT, shoot dry weight; RDWT, root dry weight; NOSR, number of secondary roots; MRPCAN, Minjigu Rock Phosphate + Calcium Ammonium Nitrate. 
growth of banana plants (Table 8). Plants treated with either fertilizer alone or inorganic fertilizer plus products performed better than plants treated with products only. Combination of ECO-T with manure plus DAP increased plant height by $33.8 \%$ and $31.2 \%$ above the sole application of manure plus DAP and ECO-T respectively. The effect of combining Rhizatech and MRPCAN on plant height was statistically the same as that of combining ECO-T and manure plus DAP. An increase of $26.5 \%$ and $59.7 \%$ above sole application of MRPCAN and Rhizatech respectively was recorded with the combined application of Rhizatech and MRPCAN. Plants treated with Rhizatech alone had statistically lower heights than all other treatments.

Similar to the observations on plant height, plants treated with the combination of Rhizatech and MRPCAN increased girth by $14 \%$ and $27 \%$, respectively compared to sole application of MRPCAN and manure plus DAP, respectively. The highest number of leaves (12) was observed on the plants treated with Rhizatech or ECO-T alone and this was statistically different from MRPCAN and ECO-T plus Mavuno-treated plants, which had the least number of leaves (10). Leaf length was significantly increased by combined application of Rhizatech and MRPCAN (32.7\%) and ECO-T plus manure and DAP (21\%). All treatments had statistically the same effects on leaf width. The trend of plant growth in the Rhodic Ferralsol is shown in Figure 2.

\subsection{Growth and Performance of Tissue Cultured Plants Treated with Microbiological Products and Different Fertilizers in Vertisol under Field Conditions}

Plant height in the Vertisol was significantly $(\mathrm{p}=0.021)$ affected by the combined application of commercial products with either inorganic or organic fertilizers in (Table 9). Combining of ECO-T with macro and micronutrients (Mavuno) increased growth of plants by 13.5\% compared to the sole addition of Mavuno and by $2 \%$ compared to the addition of ECO-T alone. Combined application of Rhizatech and with $\mathrm{P}$ and inorganic $\mathrm{N}$ increased plant height by $11.8 \%$ compared to sole addition of $\mathrm{P}$ and inorganic $\mathrm{N}$ and reduced plant height by $7 \%$ compared to sole addition of Rhizatech. The trend of plant growth in the Vertisol is shown in Figure 3.

Plant girth was enhanced by application of Rhizatech plus MRPCAN by $5.1 \%, 37.2 \%$ and $16.1 \%$ compared to sole application of Rhizatech, MRPCAN and manure plus DAP respectively. This was followed by combined application of ECO-T plus Mavuno that increased plant girth by $4.8 \%, 13.8 \%$ and $15.8 \%$ respectively compared to the sole application of ECO-T, Mavuno or manure plus DAP respectively.

Leaf width was more affected by combined application of Rhizatech and MRPCAN and ECO-T plus manure plus DAP than leaf width (the effect of the two treatments was statistically the same). Combined application of Rhizatech plus MRPCAN increased leaf length by $17 \%$, 35\% and $20.8 \%$ compared to the sole application of Rhizatech, RPCAN and manure plus DAP respectively. ECO-T plus Mavuno increased leaf length by 14\%, 13.6\% and $17 \%$ compared to the sole application of ECO-T, Mavuno and manure plus DAP.

Table 8. Growth of tissue cultured banana plants treated with microbiological products and different fertilizers, 12 months after field establishment in a Rhodic Ferralsol.

\begin{tabular}{ccccccc}
\hline Product & Fertilizer & Height $(\mathrm{cm})$ & Leaf length $(\mathrm{cm})$ & Leaf width $(\mathrm{cm})$ & No. of leaves & Girth $(\mathrm{cm})$ \\
\hline Rhizatech & None & $166.5 \mathrm{a}$ & $182.6 \mathrm{a}$ & 63.9 & $12 . \mathrm{bc}$ & 18.76 \\
ECO-T & None & $205.1 \mathrm{ab}$ & $204.7 \mathrm{ab}$ & 63.9 & $12 \mathrm{c}$ & 20.8 \\
None & Manure + DAP & $206.6 \mathrm{ab}$ & $203 \mathrm{ab}$ & 65.1 & $11 \mathrm{abc}$ & 18.2 \\
ECO-T & Mavuno & $226.7 \mathrm{bc}$ & $217.8 \mathrm{ab}$ & 65.1 & $10 \mathrm{a}$ & 21.4 \\
None & MRP + CAN & $235.8 \mathrm{bc}$ & $219.2 \mathrm{ab}$ & 66.4 & $10 \mathrm{a}$ & 20.6 \\
None & Mavuno & $245.3 \mathrm{bc}$ & $230.6 \mathrm{bc}$ & 72.8 & $11 \mathrm{abc}$ & 20.9 \\
Rhizatech & MRP + CAN & $261.6 \mathrm{c}$ & $242.4 \mathrm{bc}$ & 74.5 & $11 \mathrm{abc}$ & 23.5 \\
ECO-T & Manure + DAP & $273.7 \mathrm{c}$ & $247.9 \mathrm{bc}$ & 71.6 & $116 \mathrm{abc}$ & 23.2 \\
p value & & & & & 0.206 & 0.160 \\
Product & & 0.116 & 0.193 & 0.685 & 0.359 & 0.022 \\
Fertilizer & & 0.171 & 0.496 & 0.111 & 0.001 & 0.287 \\
Product $\times$ Fertilizer & & 0.001 & 0.019 & 0.146 \\
\hline
\end{tabular}

Means of four replicates. Within the same column, means followed by the same letter are not significantly different (Tukey's HSD test) at $\mathrm{p}>0.05$. MRPCAN, Minjigu Rock Phosphate + Calcium Ammonium Nitrate. 
Table 9. Growth and performance of tissue cultured plants treated with microbiological products and different fertilizers in Vertisol, 12 months after field establishment.

\begin{tabular}{|c|c|c|c|c|c|c|}
\hline Product & Fertilizer & Height $(\mathrm{cm})$ & Leaf length (cm) & Leaf width (cm) & No. of leaves & Girth $(\mathrm{cm})$ \\
\hline Rhizatech & None & 168.6ab & 159.9ab & $50.4 \mathrm{a}$ & 6.6abc & 20.6a \\
\hline EcoT & None & 207.3ab & $195.8 \mathrm{~b}$ & $62.3 b$ & $7.8 \mathrm{c}$ & 20.1a \\
\hline None & MRP + CAN & $156.7 \mathrm{a}$ & $140.8 \mathrm{a}$ & $50.8 \mathrm{a}$ & $6 \mathrm{ab}$ & $15.8 \mathrm{~b}$ \\
\hline None & Manure + DAP & 186.5ab & $173 a b$ & $58.8 \mathrm{ab}$ & 6.3abc & $18.7 \mathrm{a}$ \\
\hline None & Mavuno & 186.2ab & 165.6ab & $58.6 \mathrm{ab}$ & 6.1abc & 19a \\
\hline Rhizatech & $\mathrm{MRP}+\mathrm{CAN}$ & 156.7ab & 179.5ab & 58.9ab & $5.5 a$ & 17.1ab \\
\hline Rhizatech & Mavuno & 183.1ab & 167.6ab & $58.9 \mathrm{ab}$ & $6.7 \mathrm{abc}$ & 17. ab \\
\hline ECO-T & Mavuno & $211.3 \mathrm{~b}$ & $195.1 \mathrm{~b}$ & $63.1 \mathrm{~b}$ & 7.1bc & $21.6 \mathrm{a}$ \\
\hline \multicolumn{7}{|l|}{$P$ value } \\
\hline Product & & 0.4 & 0.3097 & 0.8957 & 0.2189 & 0.169 \\
\hline Fertilizer & & 0.6896 & 0.6638 & 0.592 & 0.9501 & 0.7413 \\
\hline Product $\times$ Fertilizer & & 0.0157 & $<0.0001$ & 0.105 & 0.003 & $<0.0001$ \\
\hline
\end{tabular}

Means of four replicates. Within the same column, means followed by the same letter are not significantly different (Tukey's HSD test) at $\mathrm{p}>0.05$. MRPCAN, Minjigu Rock Phosphate + Calcium Ammonium Nitrate.

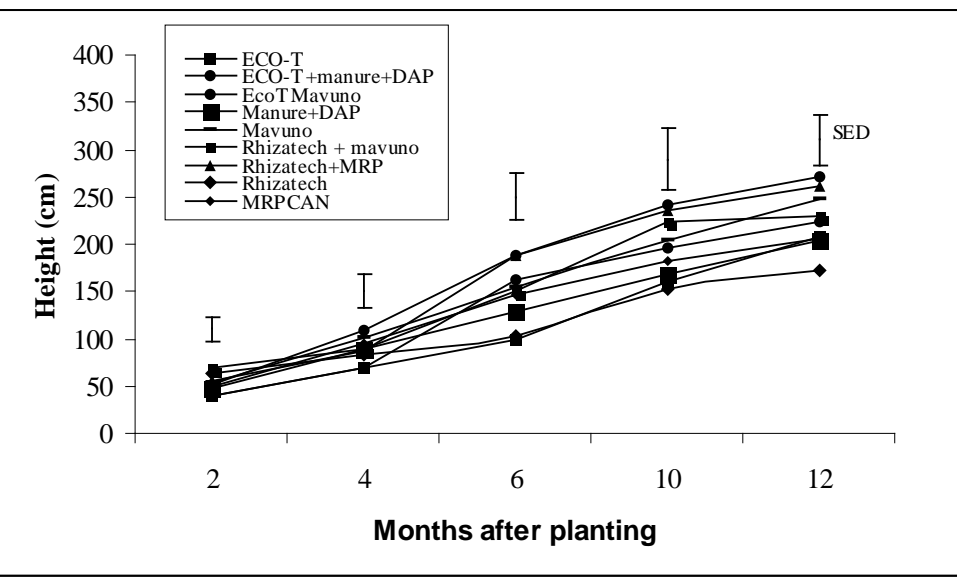

Figure 2. Growth of tissue cultured plants treated with microbiological products and different fertilizers in Rhodic Ferralsol. SED, standard error of difference between means at 12 months after field establishment.

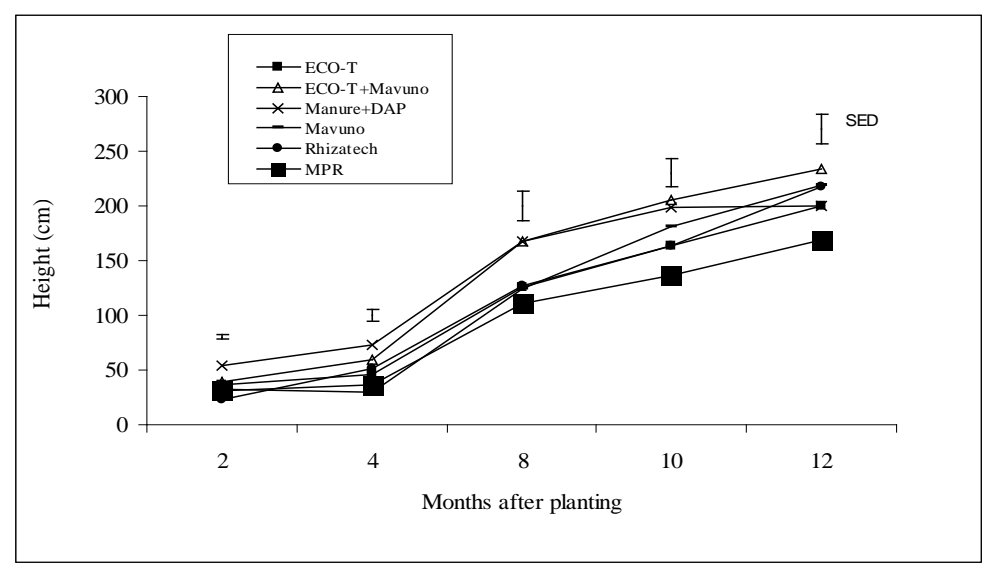

Figure 3. Growth of tissue cultured plants treated with microbiological products and different fertilizers in a Vertisol. SED, standard error of difference between means at at 12 months after field establishment. 


\section{Discussion}

The performance of tissue cultured banana plants treated with combined application of fertilizers and commercial microbiological products was variable and depended on prevailing soil conditions. Results indicate preference for certain sources of inorganic or organic nutrients by the Trichoderma based product (ECO-T) and the mycorrhiza-based product (Rhizatech). The positive effects of combining Trichoderma with organic and inorganic fertilizers were more evident in the Vertisol than that in the Rhodic Ferralsol suggesting a preference for soils with higher nitrogen levels i.e. $0.25 \%$ in the Vertisol versus $0.1 \%$ in the Rhodic Ferralsol. The performance of plants was greatly enhanced with Trichoderma combined with either organic manure inorganic phosphate diammonium phosphate) or combined with a macro and micro nutrient source (Mavuno) as compared to the sole application of Trichoderma. This indicates that organic and inorganic amendments could enhance the proliferation and efficacy of Trichoderma and subsequently enhance plant growth. Higher amounts of Trichoderma in soils with organic amendments have been reported [17]. The enhanced performance of plants when inoculated with Trichoderma combined with mineral nutrients (macro and micro nutrients) could be attributed to availability of nutrients for plant uptake as well as increased proliferation of Trichoderma populations with a consequent result of improved plant growth. Mineral nutrition is essential for growth, sporulation and stimulation of fungal secondary metabolism [18] [20] as well high total $\mathrm{N}$ availability [20]. A positive correlation between soil nitrate levels and cellulose production has also been reported [32]. Performance of plants treated with combination of mycorrhiza and either Mavuno (macro and micro nutrients) and minjigu rock phosphate was consistently better in the Rhodic Ferralsol than either mycorrhiza alone or fertilizer alone. This could suggest that the efficacy of mycorrhiza is enhanced by addition of mineral nutrients to nutrient poor soils, as is the case with the Rhodic Ferralsol [33]. This could also suggest an improved fertilizer use when mycorrhiza is combined with mineral fertilizer. This finding is in agreement with the finding of other authors who have reported that arbuscular mycorrhizal symbiosis provides numerous services to crops [34], including efficient use of fertilizer and soil nutrients [23], increased $\mathrm{N}$-fixation in legumes [35], improving plant access to mineral nutrients, including N, P, K, $\mathrm{Ca}, \mathrm{Mg}, \mathrm{Fe}, \mathrm{Cu}, \mathrm{Zn}$, and $\mathrm{Mn}$ [36]. Evaluation of the effect of biofertilizers combined with different soil amendments on potted rice plants has been reported to enhance 100-grain weight in the NPK fertilizer amendment [37].

Amendment of both the Vertisol and Rhodic Ferralsol soils with minjigu rock phosphate alone had the lowest effect on plant growth enhancement suggesting minimal solubilization and utilization of rock phosphate by plants. However, plant growth was greatly enhanced with combined application of minjigu rock phosphate and mycorrhiza (Rhizatech) indicating a positive effect of mycorrhiza in the added phosphate (P) solubilization and acquisition of by plants with a consequent increase in plant growth. This finding conforms with the reports of other authors, who have shown that mycorrhiza play an important role in effecting the availability of soil $\mathrm{P}$ to plant roots, and increasing P mobilization in soil [38] [39].

\section{Conclusion}

In conclusion, it is evident that tissue culture banana plants could greatly benefit from combined application of commercial microbiological and fertilizers. Combinations of mycorrhiza and inorganic macro and micro nutrients or rock phosphate and the combined application of Trichoderma and organic sources could greatly enhance plant growth in nutrient poor soils as was observed in the Rhodic Ferralsol and Vertisol. Knowledge of product formulations and prevailing soil conditions is essential prior to inoculation and amendment of the soils.

\section{Acknowledgements}

This work was supported by the Bill and Melinda Gates foundation through the Tropical Soil Biology Institute of CIAT (CIAT-TSBF) project on commercial microbial products. We greatly appreciate the assistance of Edwin Mutegi, Laban Nyabenga and Thomas Ngotho for field technical assistance.

\section{References}

[1] Mink, G.I. (1991) Controlling Virus Diseases Using Disease-Free Stocks. In: Pimental, D., Ed., Handbook of Pest Management in Agriculture, 2nd Edition, CRC Press, Boca Raton, 1, 363-391.

[2] Mbaka, J.N., Mwangi, M. and Mwangi, M.N. (2008) Banana Farming as a Business: The Role of Tissue Culture 
Planting Materials. Journal of Applied Biosciences 9, 354-361. www.biosciences.elewa.org

[3] Cassalls, A.C. and O’Herlihy, E.A. (2003) Disease Management of Micropropagated Plants, Good Laboratory Practice. Acta Horticulturae, 616, 105-114.

[4] Abdullah, M.Y., Hassan, Z.M. and Talib Z. (1999) Trend in Foliar Nutrient Concentrations and Contents and Its Implication on Leaf Area Index Development and Yield in Banana Cultivar "Berangan”. In: Zakaria, W., Mahmud, T.M.M., Siti Khalijah, D., Nor Aini, M.F. and Marziah, M., Eds., Proceedings of First National Banana Seminar, Awana, 95-105.

[5] Robinson, J.C. (1996) Bananas and Plantains. CAB International, Wallinford, 172-174.

[6] Khan, S.A., Mulvaney, R.L., Ellsworth, T.R. and Boast, C.W. (2007) The Myth of Nitrogen Fertilization for Soil Carbon Sequestration. Journal of Environmental Quality, 36, 1821-1832. http://dx.doi.org/10.2134/jeq2007.0099

[7] Ladha, J.K., de Brujin, F.J. and Malik, K.A. (1997) Introduction Assessing Opportunities for Nitrogen Fixation in Rice a Frontier Project. Plant and Soil, 194, 1-10. http://dx.doi.org/10.1023/A:1004264423436

[8] Ladha, J.K. and Reddy, P.M. (1995) Extension of Nitrogen Fixation to Rice: Necessity and Possibilities. Geo Journal, 35, 363-372.

[9] Mia, M.A. and Shamsuddin, Z.H. (2010) Rhizobium as a Crop Enhancer and Biofertilizer for Increased Cereal Production. African Journal of Biotechnology, 9, 6001-6009.

[10] Kennedy, I.R., Choudhury, A.T.M.A. and Kecskés, M.L. (2004) Non-Symbiotic Bacterial Diazotrophs in Crop-Farming Systems: Can Their Potential for Plant Growth Promotion Be Better Exploited? Soil Biolology and Biochemistry, 36, 1229-1244. http://dx.doi.org/10.1016/j.soilbio.2004.04.006

[11] Jeyabal, A. and Kuppuswamy, G. (2001) Recycling of Organic Wastes for the Production of Vermicompost and Its Response in Rice-Legume Cropping System and Soil Fertility. Europian Journal of Agronomy, 15, 153-170. http://dx.doi.org/10.1016/S1161-0301(00)00100-3

[12] Reino, J.L., Guerrero, R.F., Hernandez-Galan, R. and Collado, I.G. (2008) Secondary Metabolites from Species of the Biocontrol Agent Trichoderma. Phytochemistry Review, 7, 89-123. http://dx.doi.org/10.1007/s11101-006-9032-2

[13] Rodriguez-Romero, A.S., Guerra, M.S. and Jaizme-Vega, M.D. (2005) Effect of Arbuscular Mycorrhizal Fungi and Rhizobacteria on Banana Growth and Nutrition. Agronomy for Sustainable Development, 25, 395-399. http://dx.doi.org/10.1051/agro:2005039

[14] Benítez, T., Rincón, A.M., Limón, M.C. and Codón A.C. (2004) Biocontrol Mechanisms of Trichoderma Strains. International Journal of Microbiology, 7, 249-60.

[15] Harman, G.E., Howell, C.R., Viterbo, A., Chet, I. and Lorito, M. (2004) Trichoderma Species Opportunistic, Avirulent Plant Symbionts. Nature Reviews Microbiology, 2, 43-56. http://dx.doi.org/10.1038/nrmicro797

[16] Jaizme-Vega, M.C., Sosa Hernández, B. and Hernández Hernández, J.M. (1998) Interaction of Arbuscular Mycorrhizal Fungi and the Soil Pathogen Fusarium oxysporum f. sp. cubense on the First Stages of "Grande Naine” Banana. Acta Horticulturae, 490, 285-295.

[17] Okoth, S., Roimen, H., Mutsotso, B., Muya, E. and Okoth, P. (2007) Land Use Systems and Distribution of Trichoderma Species in Embu Region, Kenya. Tropical and Subtropical Agroecosystems, 7, 105-122.

[18] Griffin, D.H. (1994) Fungal Physiology. 2nd Edition, Wiley-Liss, New York.

[19] Score, A.J. and Palfreyman, J.W. (1994) Biological Control of the Dry Rot Fungus Serpula lacrymans by Trichoderma Species. International Biodeterioration and Biodegradation, 33, 115-128. http://dx.doi.org/10.1016/0964-8305(94)90031-0

[20] Fargasova, A. (1992) The Influence of Various Nitrogen Sources on the Growth, Conidiation and Pigmentation Production of the Brown Mutant of Trichoderma viridae M-108. Biology, 47, 453-464.

[21] Schubert, A. and Hayman, D.S. (1986) Plant Growth Responses to Vesicular-Arbuscular Mycorrhiza XVI. Effectiveness of Different Endophytes at Different Levels of Soil Phosphate. New Physiologist, 103, 79-90. http://dx.doi.org/10.1111/j.1469-8137.1986.tb00598.x

[22] Marschner, P. and Baumann, K. (2003) Changes in Bacterial Community Structure Induced by Mycorrhizal Colonization in Split-Root Maize. Plant and Soil, 251, 279-289. http://dx.doi.org/10.1023/A:1023034825871

[23] Javaid, A. (2009) Arbuscular Mycorrhizal Mediated Nutrition in Plants. Journal of Plant Nutrition, 32, $1595-1618$. http://dx.doi.org/10.1080/01904160903150875

[24] Atul-Nayyar, A., Hamel, C., Hanson, K. and Germida, J. (2009) The Arbuscular Mycorrhizal Symbiosis Links N Mineralization to Plant Demand. Mycorrhiza, 19, 239-246. http://dx.doi.org/10.1007/s00572-008-0215-0

[25] Bedini, S., Avio, L., Argese, E. and Giovannetti, M. (2007) Effects of Long-Term Land Use on Arbuscular Mycorrhi- 
zal Fungi and Glomalin-Related Soil Protein. Agriculture, Ecosystems \& Environment, 120, 463-466. http://dx.doi.org/10.1016/j.agee.2006.09.010

[26] Hijri, I., Sykorova, Z., Oehl, F., Ineichen, K., Mäder, P., Wiemken, A. and Redecker, D. (2006) Communities of Arbuscular Mycorrhizal Fungi in Arable Soils Are Not Necessarily Low in Diversity. Molecular Ecolology, 15, 22772289. http://dx.doi.org/10.1111/j.1365-294X.2006.02921.X

[27] Mäder, P., Fliessbach, A., Dubois, D., Gunst, L., Fried, P. and Niggli, U. (2002) Soil Fertility and Biodiversity in Organic Farming. Science, 296, 1694-1697.

[28] Anderson, J.M. and Ingram, J.S. (1993) Tropical Soil Biology and Fertility: Handbook of Methods. CAB International, Wallingford.

[29] Okalebo, J.R., Gathna, K.W. and Woomer, P.L. (2002) Laboratory Methods for Soil and Plant Analysis. A Working Manual. 2nd Edition, Tropical Soil Fertility and Biology Program, TSBF-CIAT and SACRED Africa, Nairobi, 128 p.

[30] Kavoo- Mwangi, A.M., Kahangi, E.M., Ateka, E., Onguso, J., Mukhongo, R.W., Mwangi, E.K. and Jefwa, J.M. (2013) Growth Effects of Microorganisms Based Commercial Products Inoculated to Tissue Cultured Banana Cultivated in Three Different Soils in Kenya. Applied Soil Ecology, 64, 152-162. http://dx.doi.org/10.1016/j.apsoil.2012.12.002

[31] SAS Institute Inc. (2006) SAS User’s Guide: Statistics. SAS Institute Inc., Cary.

[32] Widden, P., Cunningham, J. and Breil, B. (1989) Decomposition of Cotton by Trichoderma Species: Influence of Temperature, Soil Type, and Nitrogen Level. Canadian Journal of Microbiology, 35, 469-473. http://dx.doi.org/10.1139/m89-072

[33] FAO (2006) World Agriculture towards 2030/50. Interim Report, FAO, Rome. http://www.fao.org/es/esd/gstudies.htm

[34] Gianinazzi, S., Gollotte, A., Binet, M.N., van Tuinen, D., Redecker, D. and Wipf, D. (2010) Agroecology: The Key Role of Arbuscular Mycorrhizas in Ecosystem Services. Mycorrhiza, 20, 519-530. http://dx.doi.org/10.1007/s00572-010-0333-3

[35] Barea, J.M., Azcon, R. and Azcon-Aguilar, C. (1983) Interactions between Phosphate Solubilizing Bacteria and VA Mycorrhiza to Improve Plant Utilization of Rock Phosphate in Non-Acidic Soils. 3rd International Congress on Phosphorus Compounds, Brussels, 4-6 October 1983, 127-144.

[36] Liu, A., Hamel, C., Hamilton, R.I., Ma, B.L. and Smith, D.L. (2000) Acquisition of Cu, Zn, Mn, and Fe by MycorrHizal Maize (Zea mays L.) Grown in Soil at Different P and Micronutrient Levels. Mycorrhiza, 9, 331-336. http://dx.doi.org/10.1007/s005720050277

[37] Javaid, A. (2011) Effects of Biofertilizers Combined with Different Soil Amendments on Potted Rice Plants. Chilean Journal of Agricultural Resources, 71, 157-163. http://dx.doi.org/10.4067/S0718-58392011000100019

[38] Toro, M., Azcón, R. and Barea, J.M. (1997) Improvement of Arbuscular Mycorrhiza Development by Inoculation of Soil with Phosphate-Solubilizing Rhizobacteria to Improve Rock Phosphate Bioavailability $\left({ }^{32} \mathrm{P}\right)$ and Nutrient Cycling. Applied and Environmental Microbiology, 63, 4408-4412.

[39] Smith, S.E. and Read, D.J. (2008) Mycorrhizal Symbiosis. 3rd Edition, Elsevier Academic Press, Amsterdam, 787. 
Scientific Research Publishing (SCIRP) is one of the largest Open Access journal publishers. It is currently publishing more than 200 open access, online, peer-reviewed journals covering a wide range of academic disciplines. SCIRP serves the worldwide academic communities and contributes to the progress and application of science with its publication.

Other selected journals from SCIRP are listed as below. Submit your manuscript to us via either submit@scirp.org or Online Submission Portal.
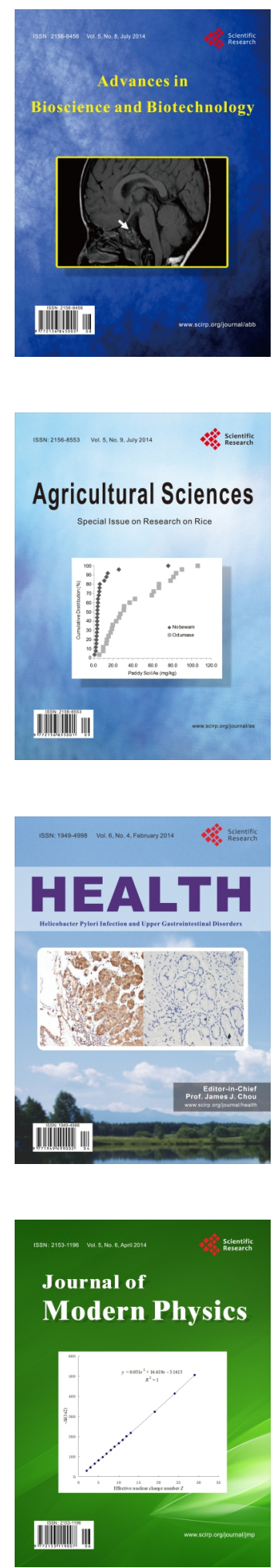
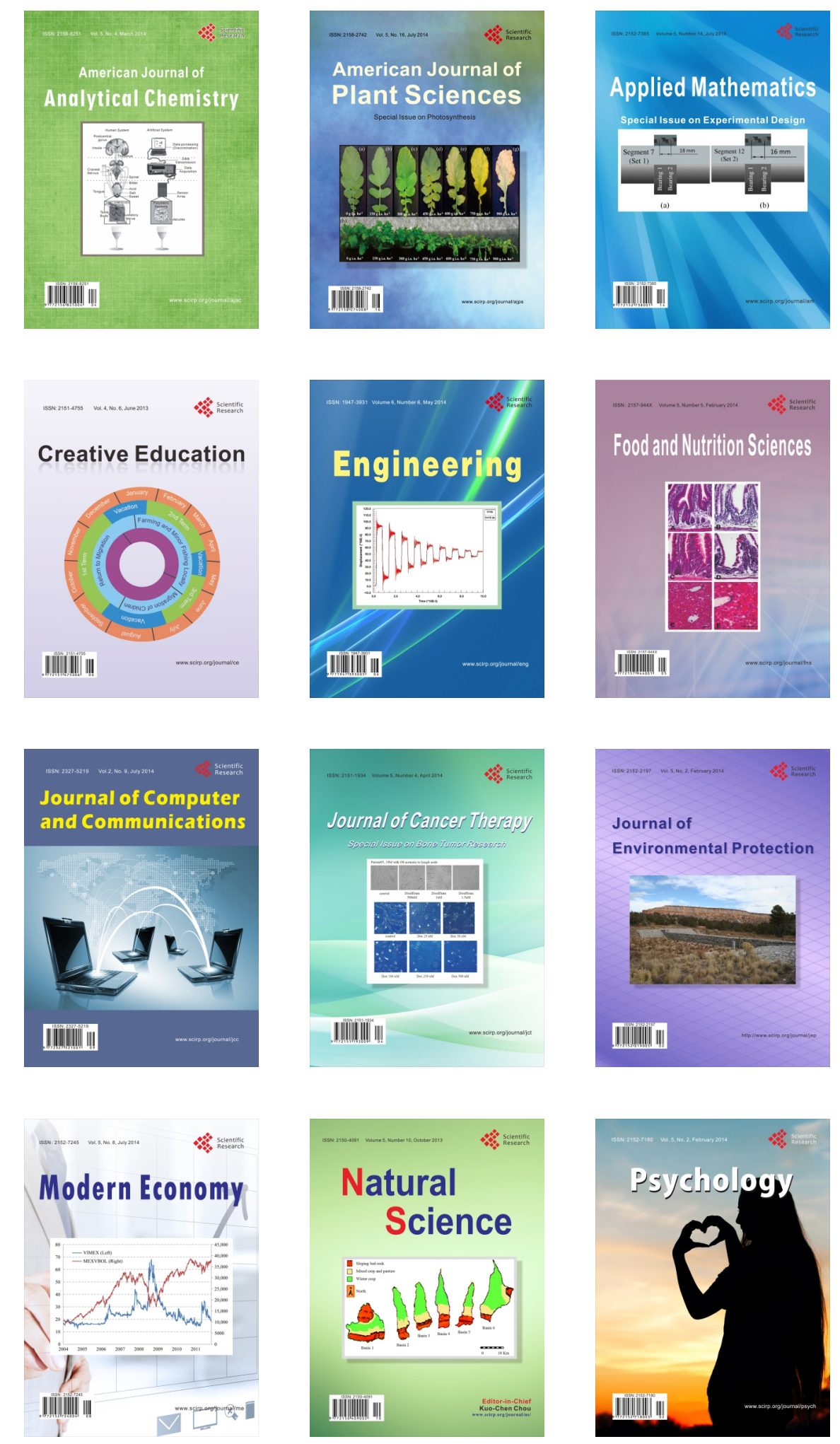